\title{
PENGARUH TEKANAN PEMBRIKETAN TERHADAP KARAKTERISTIK MEKANIK DAN KARAKTERISTIK PEMBAKARAN PADA BRIKET CAMPURAN SEKAM PADI DAN BONGGOL JAGUNG
}

\author{
SRI SURYANINGSIH *, ASNI ZAKA NURUSYSYIFA \\ Departemen Fisika Fakultas MIPA Universitas Padjadjaran, \\ Jl. Raya Bandung-Sumedang Km 21,Jatinangor 45363 \\ *email : sri@phys.unpad.ac.id
}

\begin{abstract}
Abstrak. Penggunaan biomassa sebagai bahan bakar alternatif lebih effisien dengan cara dikonversi dalam bentuk padatan berupa briket. Untuk memenuhi standar pemasaran briket harus memiliki kualitas yang baik dari segi ketahanan dan pembakaran, karena itu penting untuk membuat briket lokal dari arang sekam padi dan bonggol jagung yang memiliki kekuatan mekanis dan karakteristik pembakaran yang baik yang setara dengan standar briket nasional. Proses pembuatan briket diawali dengan pengumpulan arang sekam padi dan bonggol jagung yang kemudian dihancurkan sampai ukuran tertentu untuk kemudian dicampur dengan perekat berupa tapioka seberat6 \% dari berat bahan briket. Komposisi yang digunakan adalah 50\% arang sekam padi dan 50\% arang bonggol jagung. Variasi tekanan yang digunakan pada pembuatan briket, adalah $15 \mathrm{~kg} / \mathrm{cm}^{2}, 35 \mathrm{~kg}$ $/ \mathrm{cm}^{2}, 55 \mathrm{~kg} / \mathrm{cm}^{2}$ dan $75 \mathrm{~kg} / \mathrm{cm}^{2}$. Briket yang terbentuk kemudian diuji dengan uji kuat tekan dan uji pembakaran. Hasil penelitian menunjukkan bahwa penambahan tekanan pada pembuatan briket akan menaikan nilai kekuatan mekanik dan memperlambat waktu pembakaran, namun penambahan tekanan mencapai titik maksimal pada nilai $75 \mathrm{~kg} / \mathrm{cm}^{2}$, sebesar $0,28 \mathrm{~kg} / \mathrm{cm}^{2}$ dan lama waktu pembakaran adalah 129 menit dengan laju pembakaran adalah $0,3488 \mathrm{~g} / \mathrm{menit}$.
\end{abstract}

Kata kunci: sekam padi, bongkol jagung, tekanan pembriketan, laju pembakaran

\begin{abstract}
The use of biomass as an alternative fuel is more efficient by being converted in the form of solids as briquettes. Due to its durability and combustion quality must have fulfill the marketing standard requirement, it's important to make local briquettes from rice husk charcoal and corncob that have a good mechanical strength and good combustion characteristics which meets national briquette standards. The process of making briquettes begins with the collection of rice husk charcoal and corncob which are then crushed to a certain size and then mixed with tapioca glue weighing $6 \%$ of the weight of the briquette material. The composition used to be $50 \%$ rice husk charcoal and $50 \%$ corncob charcoal. The pressure variations used in the manufacture of briquettes are $15 \mathrm{~kg}$ $/ \mathrm{cm}^{2}, 35 \mathrm{~kg} / \mathrm{cm}^{2}, 55 \mathrm{~kg} / \mathrm{cm}^{2}$ and $75 \mathrm{~kg} / \mathrm{cm}^{2}$. Briquettes that have been formed are then examined by a compressive strength test and a combustion test. The results showed that the addition of pressure on the manufacture of briquettes would increase the value of mechanical strength and slow the combustion time, however the addition of pressure will reach the maximum point at the value of $75 \mathrm{~kg} / \mathrm{cm}^{2}$, amounting to $0.28 \mathrm{~kg} / \mathrm{cm}^{2}$ and the burning time is 129 minutes with the combustion rate was $0,3488 \mathrm{~g} /$ minute.
\end{abstract}

Keywords: rice husk, corncob, briquette pressing, burning rate

\section{Pendahuluan}

Bahan bakar merupakan suatu bahan yang dapat digunakan sebagai proses pembakaran pada saat proses tersebut bahan akan melepaskan kalor yang akan 
menghasilkan energi berupa energi panas [1]. Di negara Indonesia tingkat konsumsi penggunaan bahan bakar mempunyai nilai yang tinggi untuk setiap tahunnya, menurut badan penelitian statistical review of world energy, didapatkan pada tahun 2006 sampai dengan 2015 hasil penyediaan sebesar 996 bpd - 825 bpd dan konsumsi bahan bakar minyak sebesar 1.303 bpd - 1628 bpd dimana terdapat peningkatan terhadap nilai konsumsi bahan bakar minyak dengan rendahnya nilai ketersediaannya yang tidak dapat memenuhi kebutuhan tersebut. Penggunaan bahan bakar minyak dengan skala besar dapat menyebabkan tingkat ketersediaannya yang semakin menipis karena energi tidak terbarukan tersebut akan habis pada selang jangka waktu tertentu [2].

Untuk mengatasi persediaan energi dan mengurangi tingkat konsumsi dari penggunaan energi tak terbarukan dapat dilakukan dengan menggunakan energi baru terbarukan yaitu energi alternatif berupa biomassa. Biomassa berasal dari bahan biologis yang hidup dan sangat berpotensi digunakan dinegara Indonesia yang memiliki iklim tropis, bahan biomassa antara lain yaitu produk dari hasil pertanian, perkebunan dan pertenakan seperti pohon daun kotoran hewan serta limbah pertanian dan perkebunan. Salah satu limbah pertanian dan perkebunan yang sudah dijadikan bahan bakar adalah batok kelapa, kayu dan digunakan bisa sekacaara langsung dan briket. Limbah pertanian lain yang umumnya digunakan berasal dari produk-produk pangan seperti sekam padi dan bonggol jagung, karena tingkat produksinya yang sangat besar dimana padi merupakan bahan pokok utama untuk memenuhi kebutuhan pangan di Indonesia maka akan menghasilkan jumlah yang cukup besar dan melimpah dan dapat menyebabkan pencemaran lingkungan apabila tidak ditanggulangi dengan baik. Oleh karena itu untuk mengurangi limbah dari hasil petanian tersebut dapat dimanfaatkan sebagai bahan bakar biomassa [3].

Penggunaan biomassa sebagai bahan bakar lebih effesien dengan cara dikonversi dalam bentuk padat, cair dan gas. Biomassa yang dipadatkan akan menghasilkan produk berupa arang dari proses karbonisasi (pirolisis) dengan suhu tinggi untuk mengasilkan karbon yang berkualitas, karna karbon merupakan sumber yang baik sebagai bahan bakar, menurut penelitian Taufik Iskandar arang dengan menggunakan sekam padi didapatkan nilai kalor sebesar $3705 \mathrm{kal} / \mathrm{gram}$ pada suhu pirolisis $500^{\circ} \mathrm{C}$, sedangkan nilai kalor pada arang dengan menggunakan bonggol jagung didapatkan sebesar $7111 \mathrm{kal} / \mathrm{gram} \mathrm{[4].}$

Padatan dari arang bisa dijadikan lebih praktis, murah dan ramah lingkungan apabila dibentuk menjadi sebuah briket. Pada proses pembriketan dilakukan dengan memberikan tekanan pengepresen tertentu sehingga dapat dibentuk menjadi sebuah briket. Menurut Maninder, peralatan yang digunakan dalam pembriketan dikategorikan ke dalam beberapa jenis antara lain densifikasi tekanan piston (Piston press densification), pelet (Pelletizing) dan tekanan rendah atau press manual (Low pressure or manual presses) [5]. Besar penekanan pembriketan yang diberikan akan sangat berpengaruh terhadap kualitas briket yang dihasilkan, dimana tekanan pembriketan ini akan mempengaruhi sifat dari briket yaitu seperti sifat mekanik yang dimiliki pada briket seperti densitas, kuat tekan, stabilitas, drop test dan durabilitas pada briket. Menurut penelitian Feta Kukuh Pambudi, Wahidin Nuriana dan Hantarum pada pemberian besar penambahan pembebanan dengan variasi 45 $\mathrm{kg}-150 \mathrm{~kg}$ diperoleh nilai densitas yang dihasilkan semakin meningkat yaitu 0,39 $\mathrm{g} / \mathrm{cm}^{3}-0,47 \mathrm{~g} / \mathrm{cm}^{3}$ dan pada uji kuat tekan yang dihasilkan yaitu $52,89 \mathrm{~N} / \mathrm{cm}^{2}-$ $55.34 \mathrm{~N} / \mathrm{cm}^{2}$. Karateristik mekanik ini akan menyebabkan briket mempunyai katahanan yang baik dimana pada partikel penyusun briket akan mempunyai sifat 
kehomogenan yang baik serta briket akan lebih kokoh, tidak mudah rapuh dan dapat menyebabkan nilai jual yang tinggi pada briket [6].

Selain itu besar penekanan pembriketan yang diberikan juga akan sangat berpengaruh terhadap sifat termal pada briket yaitu seperti kadar air, laju pembakaran, waktu pembakaran dan suhu maksimal yang dihasilkan pada proses pembakaran pada briket. Menurut penelitian Feta Kukuh Pambudi, Wahidin Nuriana dann Hantarum pada pemberian besar penambahan pembebanan dengan variasi $45 \mathrm{~kg}$ - $150 \mathrm{~kg}$ diperoleh nilai kadar air yang menurun yaitu berkisar antara $12,7 \%-6,6 \%$, kemudian untuk laju pembakaran yang dihasilkan yaitu $0,57 \mathrm{~g} / \mathrm{menit}$ - 0,35 g/menit dan waktu pembakaran yang dihasilkan yaitu meninngkat yaitu berkisar antara 52.89 menit - 55.717 menit [7].

Untuk mengoptimalkan pemanfaatan limbah sekam padi menjadi sumber bahan bakar alternatif maka perlu adanya optimalisasi dalam peningkatan efektifitas dan efisiensi dari sumber bahan bakar alternatif menjadi briket arang. Tujuan penelitian ini untuk mengamati karateristik mekanik (densitas, kuat tekan) dan karateristik pembakaran (laju pembakaran) berdasarkan pengaruh besar tekanan pembriketan

\section{Metode Penelitian}

Bahan yang digunakan arang sekam padi yang berfungsi sebagai bahan utama pada pembuatan briket, dan arang bonggol jagung yang berfungsi sebagai bahan yang akan dicampurkan sebagai briket, serta tepung kanji yang befungsi sebagai bahan perekat. Metode eksperimen dari penelitian ini terdiri dari pembuatan briket, uji kareteristik briket yaitu uji mekanik (densitas dan kuat tekan) dan uji pembakaran (laju pembakaran).

Proses awal dalam pengolahan bahan baku yaitu penghalusan bahan baku berupa arang sekam padi dan bonggol jagung dan dengan tujuan untuk membuat partikel bahan baku arang ini bisa lebih kecil dan homogen sehingga akan lebih mudah dalam pencampuran (pembuatan) briket nantinya. Ukuran partikel arang yang dihasilkan dari tahapan ini adalah 100 mesh.

Briket dibuat dengan perbandingan komposisi 50\%:50\% dan dengan perekat tapioka 6\%. Pembebanan tekanan yang dipakai $15 \mathrm{~kg}, 35 \mathrm{~kg}, 55 \mathrm{~kg}$, dan $75 \mathrm{~kg}$. Briket untuk pengujian mekanik dibuat dengan ukuran diameter $4,233 \mathrm{~cm}$ dan tinggi sebesar $11,475 \mathrm{~cm}$. Sedangkan untuk pengujian pembakaran dibuat diameter $4,233 \mathrm{~cm}$ dan berat 70 gram.

\section{Hasil dan Pembahasan}

Densitas mempunyai peran penting dalam penentuan kualitas briket, nilai densitas yang tinggi menunjukan tingkat kekokohan dan kekompakan partikel penyusun pada briket. Densitas merupakan perbandingan antara massa briket dengan volume briket, semakin besar nilai densitas pada suatu briket maka ruang atau volume yang dibutuhkan akan semakin kecil dengan besar massa yang sama [7].

Densitas merupakan besar banyaknya massa pada setiap ukuran satuan volume yang dimiliki oleh sebuah briket, berdasarkan hasil densitas pada briket campuran sekam padi dan bonggol jagung dengan presentase (50:50) dengan variasi pembebanan pembriketan dapat dilihat pada Tabel 1 . 
Tabel 1. Hasil pengukuran densitas pada briket

\begin{tabular}{ccc}
\hline Sampel & Pembebanan $(\mathrm{kg})$ & Densitas $\left(\mathrm{kg} / \mathrm{cm}^{3}\right)$ \\
\hline 1 & 15 & 0,57 \\
2 & 35 & 0,63 \\
3 & 55 & 0,66 \\
4 & 75 & 0,71 \\
\hline
\end{tabular}

Nilai densitas yang dihasilkan briket campuran sekam padi dan bonggol jagung dengan konsentrasi $50: 50$ sampel briket dengan pembebanan $15 \mathrm{~kg}$ yaitu sebesar $0,57 \mathrm{gr} / \mathrm{cm}^{3}$, pembebanan $35 \mathrm{~kg}$ yaitu sebesar $0,63 \mathrm{gr} / \mathrm{cm}^{3}$, pembebanan $55 \mathrm{~kg}$ yaitu sebesar $0,66 \mathrm{gr} / \mathrm{cm}^{3}$, dan pada sampel briket dengan pembebanan $75 \mathrm{~kg}$ memiliki nilai densitas yang paling besar yaitu sebesar $0,71 \mathrm{gr} / \mathrm{cm}^{3}$. Nilai densitas yang dihasilkan memiliki nilai yang menaik ketika diberikan penambahan besar pembebanan pembriketan.

Hasil pengujian kuat tekan dengan menggunakan alat UTM (Universal Testing Mechine) yang ditunjukan dalam grafik pada Gambar 1. Nilai kuat tekan pada sampel briket campuran sekam padi dan bonggol jagung dengan presentase (50:50) dengan variasi pembebanan $15 \mathrm{~kg}, 35 \mathrm{~kg}, 55 \mathrm{~kg}, 75 \mathrm{~kg}$, yaitu dengan rentang sebesar $0,05 \mathrm{~N} / \mathrm{cm}^{2}-0,28 \mathrm{~N} / \mathrm{cm}^{2}$.

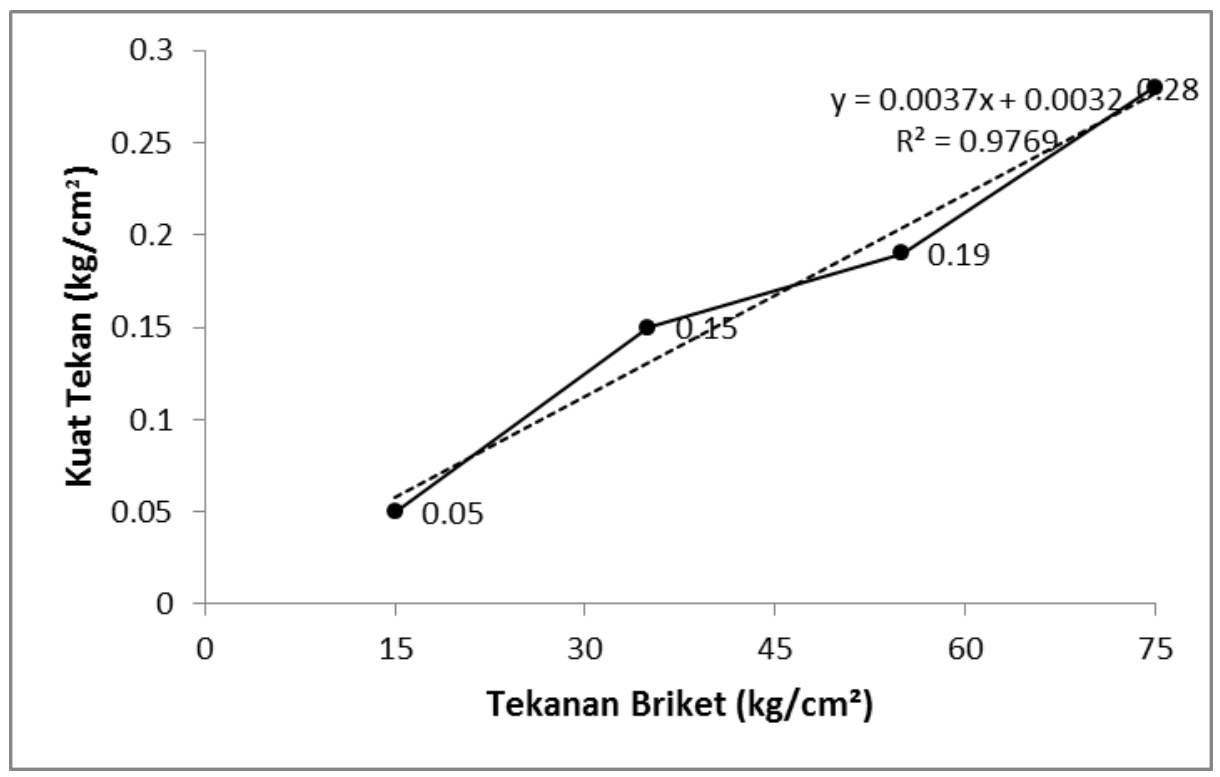

Gambar 1. Grafik Tekanan Briket terhadap Kuat Tekan

Nilai kuat tekan yang dihasilkan yaitu akan semakin meningkat seiring dengan penambahan pembebanan pembriketan yang diberikan, dimana ketika briket memiliki nilai pembebanan yang besar maka briket tersebut akan memiliki kemampuan untuk menerima tekanan dengan nilai gaya yang besar. Hal ini dikarenakan pada briket dengan tekanan terbesar mempunyai nilai densitas yang besar sehingga partikel-partikel penyusun briket akan mempunyai ikatan yang lebih kuat. 
Laju pembakaran merupakan perbandingan antara banyaknya massa yang terbakar dengan lama waktu selama proses pembakaran. Pada Tabel 2 dan Gambar 2 dapat dilihat besar nilai laju pembakaran yang dihasilkan terhadap nilai tekanan pembeban $15 \mathrm{~kg}, 35 \mathrm{~kg}, 55 \mathrm{~kg}$, dan $75 \mathrm{~kg}$. Waktu pembakaran meningkat tinggi dari 84 menit sampai 129 menit, maka laju pembakaran menurun dari 0,0105 g/s sampai $0,0058 \mathrm{~g} / \mathrm{s}$ atau $0,6309 \mathrm{~g} / \mathrm{menit}$ sampai $0,3488 \mathrm{~g} / \mathrm{menit}$. Banyaknya waktu pembakaran briket ini akan mempengaruhi nilai laju pembakaran yang dihasilkan dimana semakin lama proses pembakaran briket maka nilai laju pembakaran yang dihasilkan akan semakin menurun

Tabel 2. Hasil Uji Laju Pembakaran

\begin{tabular}{ccccccc}
\hline Sampel & $\begin{array}{c}\text { Pembebanan } \\
(\mathrm{Kg})\end{array}$ & $\begin{array}{c}\text { Massa } \\
\text { Awal (kg) }\end{array}$ & $\begin{array}{c}\text { Massa } \\
\text { Akhir }(\mathrm{kg})\end{array}$ & $\begin{array}{c}\text { Waktu } \\
\text { Pembakaran } \\
(\mathrm{s})\end{array}$ & $\begin{array}{c}\text { Laju } \\
\text { Pembakaran } \\
(\mathrm{g} / \text { menit })\end{array}$ & $\begin{array}{c}\text { Suhu } \\
\text { Pembakaran } \\
\left({ }^{\circ} \mathrm{C}\right)\end{array}$ \\
\hline 1 & 15 & 74 & 21 & 5040 & 0,6309 & 137 \\
2 & 35 & 73 & 26 & 6120 & 0,4608 & 150 \\
3 & 55 & 70 & 21 & 6660 & 0,4414 & 143,5 \\
4 & 75 & 73 & 28 & 7740 & 0,3488 & 135,5 \\
\hline
\end{tabular}

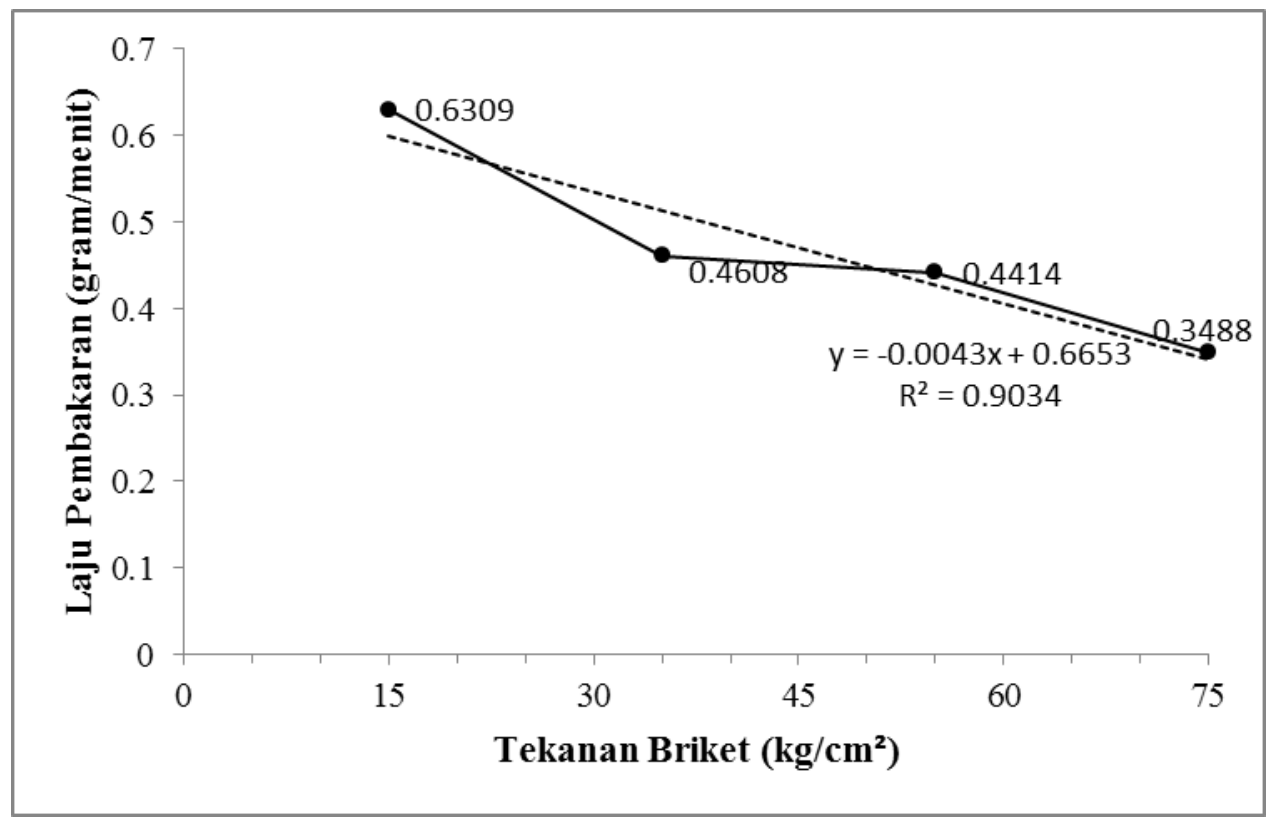

Gambar 2. Grafik Hasil Uji Laju Pembakaran Briket terhadap Variasi Pembebanan Pembriketan

Selain itu durasi waktu pembakaran briket arang bergantung pada tekanan pembebanan yaitu $15 \mathrm{~kg}, 35 \mathrm{~kg}, 55 \mathrm{~kg}, 75 \mathrm{~kg}$ dan ukuran mesh sebesar 100 mesh. Semakin besar tekanan dengan ukuran mesh yang besar menghasilkan lama waktu uji nyala yang terlama dan menghasilkan laju pembakaran rendah. Hal ini disebabkan terjadi rambatan panas atau perpindahan panas secara konduksi semakin cepat sehingga akan menghasilkan waktu nyala semakin lama dan suhu pembakaran makin menurun. 


\section{Kesimpulan}

Tekanan pembriketan dapat mempengaruhi karateristik mekanik briket yang mengakibatkan ketahanan dan kekerasan briket semakin baik dengan besar peningkatan pembebanan pembriketan. Pada tekanan optimum $75 \mathrm{~kg}$ diperoleh uji densitas sebesar 0,694 $\left(\mathrm{gr} / \mathrm{cm}^{3}\right)$, kuat tekan $0,28\left(\mathrm{~N} / \mathrm{cm}^{2}\right)$. Nilai kuat tekan yang dihasilkan semakin meningkat seiring dengan penambahan pembebanan pembriketan.

Efek tekanan pembriketan dapat mempengaruhi karateristik pembakaran briket yang mengakibatkan mudahnya penyalaan awal briket dan semakin besarnya waktu pembakaran briket sehingga pada laju pembakaran briket bernilai semakin rendah dengan besar peningkatan pembebanan pembriketan yang diberikan, pada tekanan optimum $75 \mathrm{~kg}$ diperoleh laju pembakaran sebesar $0,0058 \mathrm{~g} / \mathrm{s}$, suhu maksimal pembakaran sebesar $135,5^{\circ} \mathrm{C}$, waktu pembakaran 129 menit.

\section{Ucapan Terima Kasih}

Ucapan terima kasih ditujukan pada Departemen Fisika khususnya Kepala Laboratorium Fisika Energi yang memberikan bantuan dalam bentuk peralatan eksperimen maupun diskusi selama penelitian.

\section{DaftarPustaka}

1. D. Kira. Diktat Ilmu Bahan, Bahan Bakar dan Pelumas,14 April 2015. https://www.scribd.com/document/261816944/BAHAN-BAKAR-pdf.

2. Indonesia Investment, 4 Juli 2016. Minyak Bumi. https://www.Indonesiainvestments.com/id/bisnis/komoditas/minyak-bumi/item 267.

3. A. Tajalli. Panduan penilaian Potensi Biomassa Sebagai Sumber Energi Alternatif Di Indonesia. Penabulu Alliance. (2015) Hal. 6-7.

4. B. Gandhi, Aquino. Pengaruh Variasi Jumlah Campuran Perekat Terhadap Karateristik Briket Arang Tongkol Jagung. SMK Negri 7. (2010) Semarang. https://media.neliti.com/media/publications/161364-ID-none.pdf.

5. Maninder. Using Agricultural Residues As A Biomass Briquetting: An Alternative Source Of Energy. Journal of Electrical and Electronics Engineering. Vol. 1 (2012) pp. 11-15.

6. F.K. Pambudi, Wahidin, Nuriana, Hantarum. Pengaruh Tekanan Terhadap Kerapatan, Kadar Air dan Laju Pembakaran Pada Biobriket Limbah Kayu Sengon. Seminar Nasional Sains dan Teknologi Terapan VI 2018, Institut Teknologi Adhi Tama Surabaya.

7. R. Sunaryo, A. Prasetyo, Anang. Uji Karateristik Fisik dan Mekanik Bahan Bakar Briket Campuran Serbuk Kayu dan Lateks sebagai Energi Alternatif. http://www.digilib.ump.ac.id/files/disk1/34/jhptump-ump-gdl-sunaryoabr1685-2-hal.469-9.pdf. 